\title{
PEMBERITAAN PEMBUBARAN ORGANISASI FRONT PEMBELA ISLAM (Framing mediaindonesia.com dan kompas.com)
}

\author{
Elina Novianti Pratiwi ${ }^{1}$, Yayu Sriwartini ${ }^{{ }^{*}}$ \\ ${ }^{1}$ Program Studi Ilmu Komunikasi, Universitas Nasional Jakarta \\ Email: elinavianti@gmail.com,yayu_sriwartini@yahoo.com \\ *Korespondensi penulis: yayu_sriwartini@yahoo.com
}

(Submission 25-03-2021, Revisions 29-04-2021, Accepted 24-05-2021)

\begin{abstract}
The purpose of this research was to see the framing of the news about the dissolution of the mass organization of the Islamic Defenders Front (FPI) by mediaindonesia.com and kompas.com. This research used a qualitative approach and framing analysis method with the Zhongdang Pan \& Kosicki model. There were four (4) framing tools used to analyze, namely (1) Syntax, (2) Script, (3) Thematic, (4) Rhetorical. The research objects were five (5) news of the disbandment of FPI on mediaindonesia.com and three (3) news of that on kompas.com. Data analysis was carried out by analyzing news based on semantic, script, thematic and rhetorical structures. The results showed that mediaindonesia.com constructed the disbandment of the FPI mass organization as an appropriate government step, based on legal grounds, not making it up and there was no element of sentiment towards FPI because the decision had referred to the right legal basis. The framing of the disbandment of the Islamic Defenders Front (FPI) community organization on mediaindonesia.com supported the government by providing government sources and quotations from sources who supported the government. Meanwhile, Kompas.com was more supportive of the community with sources from within the community and quotations from sources who supported the community. The construction process carried out by the two mass media has represented the stages of construction described by the social reality construction theory of mass media.
\end{abstract}

Keywords: framing, news, FPI disbandment, mediaindonesia.com, kompas.com

\begin{abstract}
Abstrak
Tujuan penelitian ini adalah untuk melihat pembingkaian (framing) pemberitaan pembubaran organisasi massa Front Pembela Islam (FPI) oleh mediaindonesia.com dan kompas.com. Penelitian menggunakan pendekatan kualitatif dan metode analisis framing dengan model Zhongdang Pan \& Kosicki. Ada empat (4) perangkat framing yang digunakan untuk menganalisis yaitu (1) sintaksis, (2) skrip, (3) tematik, (4) retoris. Obyek penelitian adalah lima (5) pemberitaan pembubaran FPI di mediaindonesia.com dan tiga (3) pemberitaan di kompas.com. Analisis data dilakukan dengan menelaah berita berdasarkan pada struktur semantik, skrip, tematik dan retoris. Hasil penelitian menunjukkan mediaindonesia.com mengonstruksi peristiwa pembubaran organisasi massa FPI sebagai sebuah langkah
\end{abstract}


pemerintah yang tepat, berdasarkan landasan hukum, tidak ada unsur sentimen kepada FPI sebab keputusan tersebut telah mengacu pada landasan hukum yang tepat. Pembingkaian pembubaran organisasi masyarakat Front Pembela Islam (FPI) di mediaindonesia.com mendukung pemerintah dengan adanya narasumbernarasumber yang berasal dari pemerintahan dan kutipan-kutipan narasumber yang mendukung pemerintah. Sedangkan kompas.com lebih mendukung masyarakat dengan adanya narasumber-narasumber yang berasal dari kalangan masyarakat dan kutipan-kutipan narasumber yang mendukung masyarakat. Proses kontruksi yang dilakukan oleh kedua media massa tersebut telah merepresentasikan tahapan konstruksi yang dipaparkan oleh teori konstruksi realitas sosial media massa.

Kata kunci: framing, berita, pembubaran FPI, mediaindonesia.com, kompas.com

\section{PENDAHULUAN}

\section{Latar Belakang Masalah}

Front Pembela Islam (FPI) merupakan salah satu organisasi massa muslim terbesar di Indonesia yang didirikan oleh sejumlah tokoh ulama di tahun 1998 yang diketuai oleh KH. Ahmad Shabri Lubis. Namun, adalah Habib Rizieq Shihablah yang terkenal di masyarakat sebagai pelopor dan pimpinan organisasi dengan basis perjuangan menegakkan amar ma'ruf nahi munkar ini. Bahkan dia digelari sebagai imam besar. Dikutip dari Nursofya (2019) untuk menopang pencapaian tujuan pergerakannya, organisasi ini dilengkapi oleh lima (5) badan khusus yakni Badan Investigasi Front, Badan Anti-Teror Front, Badan Pengkaderan Front, Badan Ahli Front dan Badan Amil Zakat.

Sejak awal berdiri FPI selalu konsisten dalam memperjuangkan implementasi nilai-nilai Agama Islam di masyarakat, namun tidak jarang pergerakan dakwahnya menimbulkan kontroversi karena dalam sebagian pandangan masyarakat tertentu, tindakan anggota FPI dinilai keras, kasar bahkan mengarah pada anarkis. Setidaknya sejak tahun 1998 hingga tahun 2020, tercatat sedikitnya ada sepuluh (10) aksi massa yang digelar oleh FPI (interaktif.tempo.co) yang menimbulkan kerusuhan serta perkelahian. Tidak jarang juga FPI berani melakukan aksi protes terhadap para pejabat negeri ini. Salah satu di antaranya respon keras FPI terhadap pernyataan Soesilo Bambang Yudhoyono (SBY) di tahun 2011. Saat itu SBY yang menjabat sebagai presiden melontarkan kecaman terhadap ormas-ormas yang telah bertindak radikal dalam insiden berdarah di Cikeusik, Temanggung Pasuruan. Terhadap kasus tersebut, Majalah Berita Mingguan Tempo (Perdana, Karlina, Pramesti, 2012) menyebutkan bahwa FPI merupakan kelompok anarkis yang meresahkan masyarakat.

Bahkan dalam risetnya, Syaefudin (2014) menuliskan bahwa Front Pembela Islam (FPI) telah mengokohkan posisinya sebagai 'duri dalam daging' di tubuh bangsa ini. Pengatasnamaan agama oleh FPI selalu dilakukan tanpa ragu, sehingga terkesan seolah hanya merekalah yang beragama. Mereka seakan memonopoli kebenaran Tuhan. Terhadap realitas gerakan radikal FPI tersebut, pemerintah telah berkali-kali menggulirkan wacana membubarkan organisasi ini. 
Puncaknya, pada tanggal 30 Desember 2020 pemerintah melarang segala aktivitas dan penggunaan atribut organisasi ini melalui Surat Keputusan Bersama (suara.com, 2020). Pembubaran dan pelarangan aktivitas organisasi massa ini dikarenakan FPI tidak memiliki kedudukan hukum. Selain itu pemerintah pun melihat banyaknya tindakan anarkis serta fanatisme berlebihan yang dilakukan oleh ormas pimpinan Habib Rizieq Shihab ini. Bagi masyarakat atau kelompok tertentu yang sedari awal antipati terhadap FPI, berita pembubaran ini layaknya seperti "pecah telur" yang sudah lama dinanti. Tetapi sebaliknya bagi simpatisan FPI, keputusan tersebut dianggap bertendensi politis dan sarat ketidakadilan.

Sudah barang tentu peristiwa ini menjadi headline pemberitaan di berbagai media massa cetak, elektronik maupun media massa online. Portal-portal berita pun turut menggaungkan peristiwa ini, dua di antaranya adalah mediaindonesia.com dan kompas.com. Keduanya memiliki reputasi dan kredibilitas yang baik di mata khalayak. Selain memiliki banyak penghargaan, Media Indonesia merupakan salah satu media tertua di Indonesia, usianya saat ini sudah berusia 51 tahun. Berdiri sejak tahun 1970, sedangkan memilih kompas.com dikarenakan kompas.com adalah pionir dalam media online di Indonesia yang berdiri sejak 1995.

Namun keduanya ditengarai memiliki cara pandang yang berbeda dalam menerjemahkan peristiwa dalam bingkai berita (framing). Untuk menelaah bagaimana pembingkaian peristiwa pembubaran FPI di kedua media tersebut, tentu harus melalui analisis, yang dinamakan analisis framing. Cara sederhana analisis framing dapat digambarkan sebagai analisis untuk mengetahui bagaimana realitas, (peristiwa, aktor, kelompok atau apa saja) yang dibingkai oleh media. Pembingkaian media dilakukan oleh proses konstruksi. Framing yang digunakan dalam melihat penyajian berita dalam sebuah media dengan melihat aspek yang juga dihilangkan supaya pembaca mengingat apa yang ditulis oleh wartawan. Framing lebih melihat cara bagaimana media bercerita atas peristiwa yang terjadi dan melihat bagaimana media mengkonstruksi berita yang ada karena fakta atau peristiwa adalah hasil konstruksi (Eriyanto, 2011).

Penelitian ini fokus pada penelaahan konstruksi peristiwa pembubaran organisasi massa FPI yang dibuat oleh mediaindonesia.com dan kompas.com. Dengan menggunakan model Zhongdang Pan dan Kosicki diharapkan dapat terlihat pesan apa saja yang lebih ditonjolkan di kedua media tersebut, bagaimana alur pemberitaan dipaparkan, bagaimana tokoh digambarkan serta komponen grafis apa yang ditekankan untuk menguatkan pembingkaian. Dengan demikian tujuan penelitian ini adalah untuk menggambarkan bagaimana mediaindonesia.com dan kompas.com mengonstruksi peristiwa pembubaran FPI.

\section{TINJAUAN PUSTAKA}

\section{Teori Konstruksi Sosial Media Massa}

Penelitian ini berpijak pada Teori Konstruksi Realitas Sosial yang dicetuskan oleh Peter L. Berger dan Thomas Luckman. Pada teori ini digambarkan bahwa proses sosial melalui tindakan dan juga interaksinya. Dimana para individu menciptakan secara terus menerus realitas yang dimiliki serta dialami bersama secara subyektif. Kunci dari teori Konstruksi Realitas Sosial adalah pada dialektika 
Berger, ekstranalisasi, obyeknitivikasi, yang dipengaruhi oleh dialektika Hagel yang dipahami sebagaimana telah ditetapkan pada kolektifitas fenomena-fenomena oleh Marx (Morrisan, 2014).

Adapun karakteristik teori ini adalah menjelaskan bahwa komunikasi dianggap sebagai proses ekspresi, interaksi dan pengaruh yang selama proses tersebut perilaku manusia atau organisme lainnya mengekspresikan mekanisme psikologis, keadaan, peragai (trait), dan melalui interaksi dengan individu-individu lain sehingga menghasilkan dampak kognitif, emotif, dan perilaku. Ada beberapa asumsi dalam teori ini yakni:

Kunci dialetika dalam teori Berger ini, jika kita masukkan kedalam cara wartawan mendapatkan berita seperti ini, interaksi antara wartawan dan narasumber membentuk suatu percakapan tanya jawab dan dari tanya jawab tersebut wartawan memiliki hasil. Pada hasil tersebut wartawan tidak langsung menuliskan apa yang narasumber jabarkan, melainkan terdapat fase eskternalisasi (Eriyanto, 2011). Pada fase tersebut pertanyaan serta sudut gambaran yang diajukan wartawan dapat membatasi pandangan dari narasumber. Proses dialektika antara wartawan dengan narasumber menghasilkan kutipan-kutipan atau hasil wawancara yang sering kita baca di surat kabar dan kita lihat di televisi. Menurut teori ini, berita hanyalah drama, berita tidak mecerminkan realitas, melainkan adegan-adegan dari arena pertarungan berbagai pihak yang memiliki kaitan dengan suatu peristiwa.

Dikutip dari Bungin (2015), Parera menambahkan bahwa tiga momentum dialektika itu memunculkan suatu proses konstruksi sosial yang dilihat dari segi asal mulanya merupakan hasil ciptaan manusia, yaitu buatan interaksi intersubjektif. Proses tersebut adalah sebagai berikut:

1. Tahap menyiapkan konstruksi sosial media massa. Tahap ini direpresentasikan oleh pimpinan redaksi yang mendistribusikan tugasnya kepada setiap desk redaksi. Lalu dijalankan oleh wartawan setiap redaksi untuk melakukan peliputan dan pelaporan peristiwa yang diperoleh di lapangan. Dalam pelaporannya, berita dapat dikontruksi berpihak kepada penguasa atau kapitalisme, berpihak semua kepada masyarakat dan berpihak kepada kepentingan umum.

2. Tahap penyebaran konstruksi. Tahap ini berupa penyebaran informasi atau peristiwa secara real time melalui media massa.

3. Tahap pembentukan konstruksi. Tahap ini terbagi ke dalam tiga (3) yakni:

a) Tahap pembentukan konstruksi realitas. Di sini berita mulai dimaknai oleh masyarakat.

b) Pembentukan konstruksi citra. Sebuah pemberitaan dikemas sedemikian rupa sehingga memiliki citra tertentu.

c) Tahap konfirmasi, yakni tahap dimana baik masyarakat maupun media memberikan argumentasi. Bagi media tahapan ini penting untuk memberikan alasan melakukan konstruksi. Sedangkan bagi khalayak tahap ini penting untuk menjelaskan mengapa bersedia terlibat dalam proses konstruksi. 


\section{Analisis Framing Model Zhongdang Pan dan Kosicki}

Entman mendefinisikan framing sebagai proses pembingkaian dengan pemilihan beberapa aspek dari realitas serta membuatnya semakin menonjol dalam teks. Sedangkan analisis framing adalah analisis yang digunakan untuk melihat bagaimana media mengkonstruksikan realitas pada pemberitaannya. Analisis framing juga dipakai untuk melihat bagiamana suatu peristiwa dipahami dan dibingkai oleh media (Nurfitriyah, 2020). Salah satu model framing adalah model Zhongdang Pan dan Kosicki. Menurut Zhongdang Pan dan Kosicki ada dua (2) konsep framing yang berkaitan, yaitu konsep psikologis dimana manusia memproses informasi pada dirinya. Serta konsep sosiologis dimana konsep ini lebih melihat dari sisi kontruski sosial serta realitas. Zhongdang Pan \& Kosicki juga mengelompokkan perangkat framing menjadi empat (4) unsur yaitu, sintaksis, naskah, tematik dan juga retoris. Dalam pendekatannya Zhongdang Pan dan Kosicki membagi perangkat framing kedalam empat (4) struktur besar diantaranya adalah unsur sintaksis berhubungan dengan headline berita, lead berita, serta kutipan. Yang kedua adalah skrip yang berhubungan dengan $5 \mathrm{~W}+1 \mathrm{H}$, lalu ada tematik yang berhubungan dengan hubungan antar kalimat, dan yang terakhir adalah retoris yang berkaitan dengan foto dan grafis. (Eriyanto, 2008). Keempat struktur itu dapat digambarkan dengan tabel 1.

Tabel 1. Framing Model Zhongdang Pan dan Kosicki (Eriyanto, 2011).

\begin{tabular}{|l|l|l|}
\hline \multicolumn{1}{|c|}{ Struktur } & \multicolumn{1}{|c|}{ Perangkat framing } & \multicolumn{1}{|c|}{ Unit yang diamati } \\
\hline $\begin{array}{l}\text { SINTAKSIS } \\
\text { Cara wartawan } \\
\text { menyusun fakta }\end{array}$ & 1. Skema Berita & $\begin{array}{l}\text { headline, lead, Latar } \\
\text { Informasi, Kutipan Sumber, } \\
\text { Pernyataan, penutup }\end{array}$ \\
\hline $\begin{array}{l}\text { SKRIP } \\
\text { Cara wartawan } \\
\text { mengisahkan fakta }\end{array}$ & 2. Kelengkapan Berita & $\begin{array}{l}\text { 5W+IH } \\
\text { (Who,What.Where,When,Why, } \\
\text { How) }\end{array}$ \\
\hline $\begin{array}{l}\text { TEMATIK } \\
\text { Cara wartawan } \\
\text { menulis fakta }\end{array}$ & $\begin{array}{l}\text { 3. Detail } \\
\text { 4. Koherensi } \\
\text { 5. Bentuk Kalimat } \\
\text { 6. Kata Ganti }\end{array}$ & $\begin{array}{l}\text { Paragraf, proposisi, kalimat, } \\
\text { hubungan antar kalimat }\end{array}$ \\
\hline $\begin{array}{l}\text { RETORIS } \\
\text { Cara wartawan } \\
\text { menekankan fakta }\end{array}$ & $\begin{array}{l}\text { 7. Leksikon } \\
\text { 8. Grafis }\end{array}$ & $\begin{array}{l}\text { Kata, Idiom, Gambar/foto, } \\
\text { grafik }\end{array}$ \\
\hline
\end{tabular}

\section{Media Massa}

Media massa menurut McLuhan adalah perpanjangan alat indera kita. Melalui media massa kita dapat memperoleh informasi mengenai benda, orang atau tempat yang tidak kita alami secara langsung (Nurudin, 2004). Media massa merupakan sarana penyampaian komunikasi dan informasi yang melakukan penyebaran secara massal dan dapat diakses oleh masyarakat secara luas. Sedangkan informasi massa merupakan informasi yang diperuntukkan kepada masyarakat secara massal, bukan informasi yang hanya dikomsumsi oleh individu. Saat ini media massa terbagi menjadi dua yakni media massa konvensional (televisi, radio, 
koran, majalah, film, tabloid) serta media massa online. Keduanya memiliki perbedaan karakteristik, yakni sebagai berikut (Rulli, 20014):

1. Media Massa Konvensional.

a. Satu arah, media konvesional memiliki sifat satu arah.

b. Dikedalikan oleh kepemilikian.

c. Hanya kelas atas yang mengakses, seperi koran, radio, serta tv.

d. Terbatas, adanya batasan pada media konvesional seperti adanya sensor, pembatasan ruang.

2. Media Massa Online.

a. Publiksitas, penyebaran kepada khalayak cepat.

b. Universal, setiap pemberitaan yang diunggah dapat di lihat oleh siapa saja, bersifat umum.

c. Aktual, berisikan mengenai hal-hal terbaru.

d. Kontunitas, berkesinambungan anara pemberitaan satu dengan yang lain.

e. Priodetas, selalu ada pemberitaan baru setiap menit bahkan detik.

\section{Berita}

Freda Morris dalam bukunya Broadcast Journalism Techique (Andi, 2017) mengemukakan "News is immediate, the important, the things that have impact in our lives." Yang berarti berita adalah sesuatu yang baru, penting, dan dapat memberikan dampak bagi kehidupan manusia yang terdiri dari unsur-unsur diantaranya adalah: baru, penting, dan bermanfaat bagi kehidupan manusia.

\section{Organisasi Masyarakat Front Pembela Islam}

Front Pembela Islam atau FPI merupakan organisasi lintas ormas, dan satusatunya landasan hukum yang dipakai oleh organisasi ini adalah landasan hukum Allah, bukan landasan hukum mazhab ini dan mazhab itu (Adlin dan Bunyamin, 2002). FPI adalah organisasi yang tertutup serta telah menyebarkan jaringannya di berbagai wilayah Indonesia. FPI muncul sebagai organisasi pada tanggal 17 Agustus 1998 dengan ketua umum Habib Muhammad Rizieq Shihab dan berkembang pesat pada masa pemerintahan Presiden Habibie.

Tujuan dari organisasi FPI adalah untuk menegakkan amar makruf dan nahi mungkar disetiap aspek kehidupan serta sebagai wadah silahturahmi para ulama. Tindakan FPI sering kali dikritik oleh masyarakat dan berbagai pihak karena dalam beberapa aksinya terdapat aksi main hakim sendiri yang berujung dengan pengerusakkan hak milik orang lain. Rangkaian aksi yang sering kali disorot oleh media adalah aksi penutupan tempat perjudian, pelacuran, klub malam dan tempattempat yang diyakini sebagai tempat maksiat, ancaman terhadap warga negara tertentu, serta konflik dengan organisasi berbasis agama lain.

\section{METODOLOGI PENELITIAN}

Pendekatan pada penelitian ini adalah kualitatif. Menurut Denzin \& Lincoln, penelitian kualitatif merupakan penelitian yang menggunakan latar alamiah dengan maksud menafsirkan fenomena yang sedang terjadi, serta dilakukan dengan cara dan 
jalan yang melibatkan semua metode yang ada (Albi \& Setiawan, 2018). Metode penelitian yang digunakan pada penelitian ini adalah metode framing, model Zhondang Pan dan Kosicki, yang memiliki 4 perangkat framing diantaranya adalah sintaksis, skrip, tematik, retoris.

\section{Metode Penelitian}

Metode penelitian pada penelitian ini adalah dengan menggunakan metode framing, model Zhongdang Pan \& Kosicki, yang memiliki 4 perangkat framing diantaranya adalah sintaksis, skrip, tematik, retoris, dimana masingmasing prangkat memiliki unsurnya masing-masing, seperti sintaksis unsur yang diteliti adalah headline, lead, dan kutipan. Skrip unsur yang teliti adalah kelengkapan pemberitaam seperti $5 \mathrm{~W}+1 \mathrm{H}$, tematik unsur yang diteliti adalah hubungan antar kalimat, serta yang terakhir adalah retoris unsur yang diteliti adalah gambar dan juga grafis.

\section{Subjek dan Objek Penelitian}

Subjek penelitian menurut Moleong (2007) adalah orang pada latar penelitian yang dimanfaatkan untuk memberikan informasi tentang situasi dan kondisi latar penelitian. Subjek pada penelitian ini adalah mediaindonesia.com dan kompas.com. Sedangkan objek penelitian menurut Umar (2013) adalah di mana dan apa penelitian dilakukan. Bisa juga ditambahkan hal-hal lain apabila diperlukan. Objek penelitian ini adalah pemberitaan pembubaran organisasi masyarakat Front Pembela Islam, lima pemberitaan pada mediaindonesia.com dan kompas.com.

\section{Data dan Teknik Pengambilan data}

Data menurut Arikunto (Setya, et al, 2020) merupakan segala bentuk fakta serta angka yang dapat dijadikan bahan untu menyusun suatu informasi. Data berdasarkan sumbernya dibagi menjadi dua (2) yaitu: Data Primer dan Data Sekunder. Data penelitian ini adalah data sekunder, ialah pemberitaan pembubaran FPI di mediaindonesia.com dan kompas.com edisi 30 Desember 2020 - 5 Januari 2021, berjumlah delapan (8) pemberitaan. Tiga (3) pemberitaan pada kompas.com dan lima (5) pemberitaan di mediaindonesia.com.

\section{Teknik Analisis Pengolahan dan Analisis Data}

Dalam proses pengolahan data dilakukan langkah-langkah berikut ini:

1. Editing (pemeriksaan data), peneliti meneliti kembali data-data yang sudah terkumpul, data yang sudah terkumpul disini adalah pemberitaan mediaindonesia.com dan kompas.com edisi Desember 2020 - Januari 2021. Peneliti meneliti kembali terkait dengan kejelasan makna, kelengkapan berita.

2. Classifying (klasifikasi), Pada tahap ini, peneliti melakukan pengelompokkan pemberitaan mediaindonesia.com dan kompas.com, berdasarkan tanggal penerbitan.

3. Verifying (verifikasi), pada penelitian ini peneliti tidak melakukan melakukan tahap verifikasi karena peneliti tidak melakukan wawancara terhadap narasumber. 
4. Concluding (kesimpulan), pada tahap ini peneliti melakukan kesimpulan dari tiga tahap sebelumnya. Pada proses analisis data peneliti melakukan penelaahan pada struktur semantik, skrip, tematik dan retoris.

\section{HASIL PENELITIAN DAN PEMBAHASAN}

Analisis Framing Pemberitaan Pembubaran FPI di mediaindonesia.com

Analisis berita pertama tanggal 30 Desember 2020 dengan judul "Publik Dukung Pembubaran FPI".

Analisis Struktur Sintaksis:

a. Headline: Publik Dukung Pembubaran FPI

b. Lead: Keputusan pemerintah menghentikan kegiatan dan membubarkan organisasi kemasyarakan (ormas) Front Pembela Islam (FPI) memperoleh dukungan dari sejumlah elemen masyarakat.

c. Sumber kutipan dan pernyataan dapat dilihat pada tabel 2 .

Tabel 2. Sumber kutipan dan pernyataan.

\begin{tabular}{|c|c|}
\hline Nama \& Jabatan & Pernyataan \\
\hline $\begin{array}{l}\text { Naysirul Falah Amru (Sekretaris } \\
\text { Umum PP Baitul Muslimin } \\
\text { Indonesia) }\end{array}$ & $\begin{array}{l}\text { "FPI sering melakukan hal-hal yang tidak } \\
\text { mencerminkan keislaman dan keteduhan di } \\
\text { negara tercinta ini, ormas apapun yang } \\
\text { bersifat premanisme dan mengancam } \\
\text { Pancasila, kebhinekaan dan keutuhan NKRI, } \\
\text { sepantasnya dilarang pemerintah." }\end{array}$ \\
\hline $\begin{array}{l}\text { Lestari Moerdijat (Wakil Ketua } \\
\text { MPR-RI) }\end{array}$ & $\begin{array}{l}\text { "Kehidupan berbangsa dan bernegara harus } \\
\text { berdasarkan ketentuan yang disepakati } \\
\text { bersama. Bila ada kelompok yang melanggar, } \\
\text { ditindak tegas." }\end{array}$ \\
\hline $\begin{array}{l}\text { Ahmad M. Ali (Ketua Partai } \\
\text { NasDem }\end{array}$ & $\begin{array}{l}\text { "Fraksi Partai NasDem mengajak seluruh } \\
\text { elemen bangsa untuk mengajak ketertiban, } \\
\text { ketentraman, serta harmonisasi sosial di } \\
\text { tengah kehidupan kita bersama. Fraksi Partai } \\
\text { NasDem juga mengajak warga bangsa ini } \\
\text { menghidupakan semangat dialog, toleransi, } \\
\text { dan gotong royong." }\end{array}$ \\
\hline Mahfud MD (Menko Polhukam) & $\begin{array}{l}\text { "Saya ingin mengatakan bahwa FPI sejak } 21 \\
\text { Juni } 20219 \text { secara De Jure telah bubar } \\
\text { sebagai ormas.". dan "sebagai organisai tetap } \\
\text { melakukan aktivitas melanggar ketertiban, } \\
\text { keamanan, dan bertentangan dengan hukum } \\
\text { seperti sweeping dan provokasi". }\end{array}$ \\
\hline $\begin{array}{l}\text { Ujang Komarudin (Pengamat } \\
\text { Politik Univ. Al-Azhar) }\end{array}$ & $\begin{array}{l}\text { "Itu hak pemerintah dan negara untuk } \\
\text { membubarkan FPI dan organisasi lain jika } \\
\text { melanggar Undang-Undang. Kita harus taat }\end{array}$ \\
\hline
\end{tabular}




\begin{tabular}{|l|l|}
\hline & $\begin{array}{l}\text { pada hukum. Hukum yang berkeadilan bagi } \\
\text { semua. }\end{array}$ \\
\hline $\begin{array}{l}\text { Brigjen Rusdi Hartono (Kabiro } \\
\text { Penerangan Masyarakat Humas } \\
\text { Polri) }\end{array}$ & $\begin{array}{l}\text { kan sudah jelas, itu (FPI) organisasi yang } \\
\text { dilarang segala aktivitas maupun penggunaan } \\
\text { atribut". }\end{array}$ \\
\hline $\begin{array}{l}\text { Wakil Sekretasi Dewan Syuro } \\
\text { DPP PKB, Maman Imanullaq }\end{array}$ & $\begin{array}{l}\text { kembali menjadi momentum umat islam } \\
\text { keislamannya. Islam yang menjadi energi } \\
\text { perdamaian dan perubahan." }\end{array}$ \\
\hline
\end{tabular}

Analisis Struktur Skrip:

Mediaindonesia.com mewawancarai narasumber yang mendukung langkah pemerintah dalam membubarkan FPI seperti wakil ketua MPR-RI, wakil sekretaris dewan syuro DPP PKB, kabiro penerangan masyarakat humas polri, sekretaris umum PP Baitul muslimin Indonesia, pengamat politik Universitas Al-Azhar, menkopolhukam,dan ketua partai NasDem. FPI dibubarkan karena dinilai telah melanggar hukum yang berlaku.

Analisis Struktur Tematik:

Dalam menuliskan fakta, mediaindonesia.com menuliskan fakta-fakta di antaranya adalah bahwa Fpi sudah bubar secara de jure pada tanggal 21 Juni 2019 lalu, petugas mencopot atribut Fpi di Petamburan, Tanah Abang, Jakarta. Fakta tersebut di tuliskan secara berkaitan antara satu kalimat dengan kalimat lainnya.

Analisis Struktur Retoris:

Mediaindonesia.com. menekankan fakta, memilih foto petugas yang sedang mencopot atribut fpi di Petamburan, Tanah Abang, Jakarta. Berdasatkan keempat unsur di atas maka mediaIndonesia.com membingkai pemberitaan terkait dengan pembubaran FPI bahwa publik mendukung pembubaran FPI, hal ini di perkuat dengan kutipan dimana mediaindonesia.com mengutip pernyataan dari berbagai pihak, serta penggunaan foto pencopotan papan nama atau atribut yang dimana semakin memperkuat bahwa FPI sudah dilarang atau sudah di bubarkan oleh pemerintah.

Analisis berita kedua tanggal 1 Januari 2021 dengan judul "Mahasiswa UII Nilai Pembubaran FPI Demi Jaga Stabilitas Negara".

Analisis Struktur Sintaksis:

a. Headline: Mahasiswa UII Nilai Pembubaran FPI Demi Jaga Stabilitas Negara).

b. Lead: Pembubaran Front Pembela Islam (FPI) oleh pemerintah menuai dukungan. Langkah tersebut dianggap tepat.

c. Sumber kutipan dan pernyataan dapat dilihat pada tabel 3 . 
Tabel 3. Sumber kutipan dan pernyataan.

\begin{tabular}{|l|l|}
\hline \multicolumn{1}{|c|}{ Nama dan Jabatan } & \multicolumn{1}{c|}{ Pernyataan } \\
\hline Presiden mahasiswa (presma) & "Ini satu ketetapan yang kuat secara \\
Univeristas Islam Indonesia (UII) & $\begin{array}{l}\text { hukum serta menjadi dasar atau dalil } \\
\text { bagi pemerintah untuk tetap menjaga } \\
\text { stabilitas keamanan negara.”. }\end{array}$ \\
\hline
\end{tabular}

Analisis Struktur Skrip:

Wartawan mediaindonesia.com mengisahkan fakta pembubaran FPI dirasa tepat, karena FPI dianggap tidak memiliki izin beraktivitas sejak juni 2020 silam yang mebuat organisasiini tidak memiliki legal standing.

Analisis Struktur Tematik:

Dalam pemberitaannya, mediaindonesia.com mengusung tema ketidaklegalan organisasi FPI yang ijin operasionalnya sudah habis pada tanggal 20 Juni 2020. Hal ini ingin menekankan bahwa segala aktivitas yang dilakukan FPI setelah tanggal tersebut adalah tidak sah dan FPI dianggap tidak ada.

Analisis Struktur Retoris:

Mediaindonesia.com memilih menampilkan foto pencopotan atribut yang dilakukan oleh aparat, yang merujuk pada FPI benar-benar sudah tidak bisa beraktivitas maupun menggunkan atributnya.

Berdasarkan pada keempat unsur di atas maka mediaindonesia.com membingkai FPI sebagai organisasi yang sudah tidak sah lagi dan pembubaran merupakan langkah tepat.

Analisis berita ketiga tanggal 2 Januari 2021 dengan judul "Pembubaran FPI Punya Dasar Hukum Kuat”.

Analisis Struktur Sintaksis:

a. Headline: Pembubaran FPI Punya Dasar Hukum Kuat

b. Lead: Front Pembela Islam (FPI) telah resmi menjadi organisasi terlarang melalui Surat Keputusan Bersama (SKB) yang diteken tiga menteri dan tiga kepala negara lainnya pada Rabu (30/12/2020) silam.

c. Sumber kutipan dan pernyataan dapat dilihat pada tabel 4.

d. Kutipan Media Indonesia Tanggal 02 Januari 2021.

Tabel 4. Sumber kutipan dan pernyataan.

\begin{tabular}{|l|l|}
\hline Nama \& Jabatan & Pernyataan \\
\hline $\begin{array}{l}\text { Ahmad Basarah sebagai Ketua } \\
\text { Fraksi PDIP DPR RI }\end{array}$ & $\begin{array}{l}\text { "saya yakin sudah menjadi } \\
\text { pertimbangan yang masak dan telah } \\
\text { melalui kajian hukum yang matang" }\end{array}$ \\
\hline $\begin{array}{l}\text { Ace Hasan Syadzily sebagai Ketua } \\
\text { DPP Partai Golkar }\end{array}$ & $\begin{array}{l}\text { "Pemerintah punya dasar hukum yang } \\
\text { kuat dalam melarang aktivitas FPI" }\end{array}$ \\
\hline
\end{tabular}


Analisis Struktur Skrip:

Wartawan mediaindonesia.com mengisahkan fakta bahwa FPI sudah menjadi organisasi telarang pada tanggal 30 Desember 2020 dan penandatanganan Surat Keputusan Bersama (SKB) oleh tiga menteri dan tiga kepala lembaga lainnya, pemeritah memiliki landasan hukum yang kuat. Tidak ada sentimen dari pemerintah.

\section{Analisis Struktur Tematik:}

Tema yang diusung dalam pemberitaan tanggal 2 Januari 2021 ini tidak jauh berbeda dengan tanggal 1 Januari, yakni mengenai fakta de jure FPI yang sudah tidak sah, sebab tidak ada surat perpanjangan organisasi, sehingga keputusan pemerintah membubarkan FPI tidak melanggar hukum.

Analisis Struktur Retoris:

Mediaindonesia.com dalam menekankan fakta memilih menampilkan foto Kadivhumas Polri Irjen Pol Argo Yuwono didampingi Korepenmas Brigjen Pol Rusdi Hartato yang sedang menunjukkan surat makmulat kapolri tentang pembubarasn FPI.

Berdasarkan hasil analisis dari setiap struktur pada pemberitaan tanggal 02 Januari 2021 dapat disimpulkan mediaindonesia.com membingkai tindakan pemerintah membubarkan FPI merupakan tindakan yang legal, memiliki landasan hukum kuat, tidak asal membubarkan. Pemerintah tidak melakukan diskriminasi kepada FPI.

Analisis berita keempat tanggal 2 Januari 2021 dengan judul "Pembubaran FPI Dinilai KIB Langkah Tegas Pemerintah".

Analisis Struktur Sintaksis:

a. Headline: Pembubaran FPI Dinilai Kebangkitan Indonesia Baru (KIB) sebagai langkah tegaspPemerintah

b. Lead: Ketua Dewan Pimpinan Nasional (DPN) Kebangkitan Indonesia Baru (KIB), Maryadi menilai langkah pemerintah yang melarang dan membubarkan organisasi Front Pembela Islam (FPI) langkah tepat.

c. Sumber kutipan dan pernyataan dapat dilihat pada tabel 5 .

Tabel 5. Sumber kutipan dan pernyataan.

\begin{tabular}{|l|l|}
\hline Nama dan Jabatan & Pernyataan \\
\hline Maryadi atau Abah sebagai Ketua & "KIB mendukung sikap tegas \\
DPN Kebangkitan Indonesia Baru & pemerintah terkait pembubaran FPI \\
(KIB) & tersebut. Setiap organisasi di \\
& $\begin{array}{l}\text { Indonesia harusnya mengamalkan } \\
\text { nilai-nilai Pancasila" }\end{array}$ \\
\hline
\end{tabular}

Analisis Struktur Skrip: 
Mediaindonesia.com mengisahkan fakta bahwa Dewan Pimpinan Nasional Kebangkitan Indonesia Baru (KIB) mendukung langkah pemerintah dalam membubarkan FPI sebab organisasi tersebut dinilai merugikan masyarakat.

Analisis Struktur Tematik:

Tema yang diusung dalam pemberitaan ini adalah ketepatan dan tindakan pemerintah. Pemerintahan Jokowi dianggap tegas terhadap organisasi yang meresahkan dan apalagi sudah tidak legal.

Analisis Struktur Retoris:

Mediaindonesia.com memilih menampilkan foto sekretariat FPI yang sudah mulai dicopot atributnya oleh petugas, yang merujuk bahwa FPI sudah tidak dapat lagi beraktivitas maupun menggunakan atribut.

Berdasarkan keempat unsur diatas maka framing mediaindoesia.com adalah memposisikan Pemerintah Indonesia sebagai pemerintah yang memiliki ketegasan dan integritas serta komitmen dalam menindak organisasi terlarang, termasuk FPI. Sedangkan FPI di framing sebagai organisasi yang tidak mengindahkan asas hukum, sehingga meskipun sudah tidak memiliki ijin operasional masih tetap beraktivitas. Hal tersebut tentu melanggar aturan.

Analisis berita kelima tanggal 2 Januari 2021 dengan judul "Pembubaran FPI Mahasiswa UTM: Alasan Pemerintah Kuat".

Analisis Struktur Sintaksis:

a. Headline: Pembubaran FPI Mahasiswa UTM: Alasan Pemerintah Kuat.

b. Lead: Perwakilan mahasiswa Univeritas Trimojoyo Madura (UTM), mendukung keputusan pemerintah yang menhentikan kegiatan dan membubarkan organisasi kemasyarakatan (ormas) Front Pembela Islam (FPI).

c. Sumber kutipan dan pernyataan dapat dilihat pada tabel 6 .

Tabel 6. Sumber kutipan dan pernyataan.

\begin{tabular}{|l|l|}
\hline \multicolumn{1}{|c|}{ Nama dan Jabatan } & \multicolumn{2}{|c|}{ Pernyataan } \\
\hline Mudasir sebagai & "Hal ini diyakini sebagai langkah pemerintah \\
Wakil Badan & dengan tujuan untuk menertibkan organisasi \\
Eksekutif (BEM). & masyarakat yang kerap berjalan di luar koridor \\
UTM & hukum" \\
\hline
\end{tabular}

Analisis Struktur Skrip:

Dalam mengisahkan fakta, mediaindonesia.com lagi-lagi menonjolkan dukungan dari kalangan kampus kepada pemerintah dalam mengambil langkah tegas membubarkan FPI. Dalam pemberitaan ini mediaindonesia.com mengangkat pandangan perwakilan dari Badan Eksekutif Mahasiswa UTM.

Analisis Struktur Tematik: 
Tema yang diusung dalam pemberitaan mediaindonesia.com adalah dukungan organisasi mahasiswa kepada pemerintah. Mahasiswa diposisikan sebagai aktor yang turut mendukung kebijakan pemerintah terhadap FPI.

Analisis Struktur Retoris:

Pada pemberitaan ini mediaindonesia.com memilih menampilkan banner gambar wajah Habib Rizieq Shihab yang terpampang di pinggir sebuah jalan. Dalam banner tersebut tidak terpampang atribut FPI. Hal ini seolah menyiratkan bahwa sosok Habib Rizieq Shihab dalam banner tersebut merepresentasikan orang biasa.

Berdasarkan analisis dari keempat struktur framing Zhongdang Pan dan Kosicki, pemberitaan tanggal 2 Januari 2021 dengan judul "Pembubaran FPI Mahasiswa UTM: Alasan Pemerintah Kuat" menonjolkan kekuatan dukungan dari elemen mahasiswa kepada keputusan pembubaran FPI oleh pemerintah.

\section{Analisis Framing Pemberitaan Pembubaran FPI di kompas.com.}

Analisis berita pertama tanggal 30 Desember 2020 dengan judul "Isi Lengkap SKB Tentang Pembubaran dan Pelarangan FPI".

Analisis Struktur Sintaksis:

a. Headline: Isi Lengkap SKB Tentang Pembubaran dan Pelarangan FPI.

b. Lead: Pemerintah secara resmi telah membubarkan organisasi massa Front Pembela Islam dan melarang setiap kegiatan yang dilakukan atas nama FPI.

c. Sumber kutipan dan pernyataan dapat dilihat pada tabel 7 .

Tabel 7. Sumber kutipan dan pernyataan.

\begin{tabular}{|c|c|}
\hline Nama dan Jabatan & Pernyataan \\
\hline $\begin{array}{l}\text { Polhukam Mahfud MD } \\
\text { sebagai Menkumham RI }\end{array}$ & $\begin{array}{l}\text { "Pelanggaran kegiatan FPI ini dituangkan } \\
\text { di dalam keputusan bersama enam pejabat } \\
\text { tertinggi di kementerian dan lembaga," }\end{array}$ \\
\hline
\end{tabular}

Analisis Struktur Skrip:

Dalam mengisahkan fakta, kompas.com memunculkan fakta tentang telah resminya FPI dibubarkan pada tanggal 30 Desember 2020 dengan menuliskan isi lengkap SKB tiga (3) menteri.

Analisis Struktur Tematik:

Tema yang diusung oleh kompas.com adalah pembubaran FPI secara resmi.

Analisis Struktur Retoris:

Media kompas.com memilih memunculkan foto wakil menteri Hukum dan HAM, Eddie Hiariej saat membacakan SKB. Hal ini menunjukkan bahwa kompas.com benar-benar meliput pembacaan SKB untuk meyakinkan bahwa FPI benar-benar sudah bubar melalui SKB. 
Berdasarkan analisis keempat struktur tersebut, edisi tanggal 30 Desember 2020 membingkai fakta bahwa FPI telah benar-benar dibubarkan secara resmi dan transparan. Di satu sisi FPI diposisikan sebagai organisasi yang "spesial" sehingga pembubarannya harus diumumkan secara terbuka melalui media massa, tujuannya agar menginformasikan masyarakat bahwa FPI sudah tidak ada.

Analisis berita kedua tanggal 4 Januari 2021 dengan judul "BEM UI Kritik Pembubaran FPI Tanpa Peradilan”.

Analisis Struktur Sintaksis:

a. Headline: BEM UI Kritik Pembubaran FPI Tanpa Peradilan.

b. Lead: Badan Eksekutif Mahasiswa Universitas Indonesia (BEM UI) mengkritik langkah pemerintah membubarkan Front Pembela Islam (FPI) sebagai organisasi kemasyarakatan, tanpa proses peradilan.

c. Sumber kutipan dan pernyataan dapat dilihat pada tabel 8 .

Tabel 8. Sumber kutipan dan pernyataan.

\begin{tabular}{|l|l|}
\hline Nama dan Jabatan & \multicolumn{1}{|c|}{ Pernyataan } \\
\hline BEM UI & $\begin{array}{l}\text { Prosedur dan landasan atas keputusan dilarangnya } \\
\text { organisasi kemasyarakatan tersebut tidak } \\
\text { merefleksikan Indonesia sebagai negara hukum } \\
\text { sebagaimana ditegaskan dalam Pasal 1 Ayat (3) } \\
\text { UUD 1945, }\end{array}$ \\
\hline
\end{tabular}

Analisis Struktur Skrip:

Dalam mengisahkan fakta, kompas.com menyajikan respon ketidaksetujuan mahasiswa UI melalui Badan Eksekutif Mahasiswanya atas kebijakan pemerintah yang dinilai tidak prosedural dalam membubarkan organisasi FPI.

Analisis Struktur Tematik:

Tema yang diusung dalam pemberitan edisi 4 Januari ini adalah ketidakselarasan undang-undang ormas yang menjadi rujukan SKB dengan konsep negara hukum yang menjunjung tinggi negara berserikat.

Analisis Struktur Retoris:

Dalam pemilihan unsur retoris yang menguatkan ketiga struktur sebelumnya, kompas.com memilih mempublikasikan foto pencopatan atribut oleh aparat.

Dari hasil analisis keempat struktur tersebut dapat disimpulkan bahwa pemberitaan kompas.com tanggal 4 Januari 2021 membingkai pembubaran FPI adalah langkah yang tidak adil, diskriminatif dan melannggar hak asasi sebab tidak merefleksikan Indonesia sebagaimana yang ditegaskan dalam pasal 1 ayat 1 UUD 1945. FPI dipaksa tidak ada di negeri ini. Kompas.com menonjolkan sikap kontra 
dari kelompok mahasiswa universitas negeri, dalam hal ini direpresentasikan oleh BEM UI.

Analisis berita ketiga dengan judul "Kesalahan Pembubaran FPI Menurut Amnesty International".

Analisis Struktur Sintaksis:

a. Headline: Kesalahan Pembubaran FPI Menurut Amnesty International.

b. Lead: Amnesty International menilai, keputusan pemerintah membubarkan Front Pembela Islam (FPI) berpontensi mendiskriminasi dan melanggar hak berserikat serta berekspresi.

c. Sumber kutipan dan pernyataan dapat dilihat pada tabel 9.

Tabel 9. Sumber kutipan dan pernyataan dalam pemberitaan kompas.com tanggal 5 Januari 2021.

\begin{tabular}{|l|l|}
\hline \multicolumn{1}{|c|}{ Nama dan Jabatan } & \multicolumn{1}{c|}{ Pernyataan } \\
\hline Usman Hamid sebagai Direktur & $\begin{array}{l}\text { Sehingga semakin menggerus kebebasan } \\
\text { Eksekutif Amnesty International }\end{array}$ \\
sipil di Indonesia"
\end{tabular}

Analisis Struktur Skrip:

Dalam mengisahkan faktanya, kompas.com menuliskan pandangan hukum inernasional yang menyatakan bahwa sebuah organisasi hanya dapat di bubarkan setelah adanya keputusan dari pengadilan yang independen dan netral.

Analisis Struktur Tematik:

Tema yang diangkat oleh media kompas.com adalah kelalaian pemerintah dalam memperhatikan prosedur hukum tentang pelarangan dan pembubaran ormas.

Analisis Struktur Retoris:

Media kompas.com memilih menampilkan foto aparat yang sedang melakukan pencopotan atribut yang digunakan FPI, foto dalam konteks ini seolah menguatkan adanya pemaksaan pembubaran FPI.

Berdasarkan pada analisis keempat unsur di atas, kompas.com membingkai pemberitaan pembubaran FPI sebagai sebuah bentuk kelalaian dan ketergesa-gesaan pemerintah yang tidak memperhatikan prosedur hukum yang berlaku. Tidak adanya proses pemanggilan dan pengadilan menunjukkan pemerintah bermain hakim sendiri. Sedangkan FPI diposisikan sebagai obyek yang diperlakukan tidak adil.

\section{PEMBAHASAN}

Hasil analisis terhadap pemberitaan pembubaran FPI pada mediaindonesia.com dan kompas.com terlihat dua pembingkaian yang berbeda. Dengan metode framing Zhongdang Pan dan Kosicki diperoleh hasil mediaindonesia.com mengonstruksi peristiwa pembubaran organisasi massa FPI 
sebagai sebuah langkah pemerintah yang tepat, berdasarkan landasan hukum, tidak ada unsur sentimen kepada FPI yang terkenal menimbulkan kontroversial di masyarakat. Pemerintah digambarkan sebagai pengambil keputusan yang tegas dalam menertibkan organisasi yang dianggap radikal dan anarkis bagi sebagian masyarakat tertentu. Pemerintah diposisikan sebagai aktor penyelamat dan kelompok mahasiswa dari universitas swasta dikontruksikan sebagai pendukung keputusan pemerintah.

Penekanan yang sangat kentara tentang ketegasan dan ketepatan sangat terlihat dalam struktur sintaksis yakni judul dan juga headline. Dari lima (5) berita semuanya memperkuat langkah pemerintah. Narasumber yang dimunculkan adalah orang-orang yang ada di dalam lingkaran pemerintahan. Sosok pengamat yang ditampilkan berasal dari kalangan yang netral sehingga tidak ada kesan kontroversi dalam pemberitaan mediaindonesia.com. Pemunculan unsur grafis berupa foto petugas yang melucuti atribut FPI di sekitar Petamburan dimaknai sebagai tindakan yang benar karena bertujuan menertibtikan gerakan organisasi yang sudah dianggap ilegal.

Lain halnya dengan kompas.com dari 3 pemberitaan mengenai keputusan pembubaran FPI, satu (1) di antaranya memberitakan tentang pengumuman isi lengkap Surat Keputusan Bersama (SKB). Di sini kompas.com tidak mengangkat isu pembenaran keputusan pemerintah, tetapi hanya sekedar mempublikasikan bahwa SKB pembubaran FPI memang benar adanya. Namun sikap kompas.com terlihat kentara pada dua berita lainnya. Kompas.com mengonstruksi pemerintah bertindak tergesa-gesa, tidak prosedural, diskriminatif dan langkah pemerintah dalam membubarkan FPI dirasa dan dinilai tidak memiliki landasan hukum yang kuat serta dapat menimbulkan diskriminasi dalam berorganisasi serta berekspresi di Indonesia. Hal ini terkesan tidak menghargai hak asasi masyarakat untuk berserikat sesuai yang tercantum dalam Pasal 1 Ayat (3) UUD 1945. Landasan hukum yang pakai oleh pemerintah pun dinilai cacat. Pembingkaian tersebut terlihat pada struktur sintaksis dalam judulnya. Kompas.com menjadikan kelompok mahasiswa dari kalangan universitas negeri sebagai pihak yang berani menentang keputusan pemerintah. Dalam struktur sintaksisnya pun dikuatkan oleh pengamat dari lembaga Amnesty Internasional. Lalu secara retoris pemilihan foto petugas yang sedang mencabuti atribut FPI dianggap sebagai bentuk pemaksaan.

Jika dilihat dari teori konstruksi realitas sosial media massa. Kedua media massa tersebut telah sangat jelas melakukan upaya kontruksi terhadap peristiwa yang diliputnya. Proses eksternalisasi dilakukan dalam bentuk peliputan dan penuangan paparan peristiwa ke dalam sebuah berita. Proses obyektivasi dilakukan dengan cara menguatkan hasil peliputan dengan menambahkan menghadirkan narasumber. Dan proses internalisasi adalah penyerapan kembali informasi yang diperoleh melalui berbagai sumber untuk dirangkaian menjadi sebuah narasi yang sesuai dengan tujuan konstruksi awal. Pemilihan wartawan peliput, narasumber serta angel pemberitaan merupakan bagian dari tahap menyiapkan materi konstruksi. mediaindonesia.com lebih memilih narasumber yang berasal dari lingkungan pemerintah dan politisi pendukung pemerintah. Keberpihakan kepada penguasa sangat kentara. Sedangkan kompas.com cenderung meminta pandangan dari kaum 
intelektual. Tentu saja pemilihan-pemilihan ini bertujuan untuk memperkuat tujuan konsruksi yang dilakukan masing-masing media. Penguatan konstruksi pun terlihat dari frekuensi pemberitaan. Mediaindonesia.com menghadirkan 5 pemberitaan dengan nada serupa sedangkan kompas.com hanya 3 berita dengan 1 buah berita terlihat netral dan memperlihatkan keberpihakan kepada kepentingan umum, yakni pemberitaan mengenai isi lengkap Surat Keputusan Bersama.

\section{SIMPULAN}

Pembingkaian pembubaran organisasi masyarakat Front Pembela Islam (FPI) di mediaindonesia.com mendukung pemerintah dengan adanya narasumbernarasumber yang berasal dari pemerintahan dan kutipan-kutipan narasumber yang mendukung pemerintah. Sedangkan Kompas.com lebih mendukung masyarakat dengan adanya narasumber-narasumber yang berasal dari kalangan masyarakat dan kutipan-kutipan narasumber yang mendukung masyarakat. Proses kontruksi yang dilakukan oleh kedua media massa tersebut telah merepresentasikan tahapan konstruksi yang dipaparkan oleh teori konstruksi realitas sosial media massa.

\section{DAFTAR PUSTAKA}

Adlin, Sila M dan Buyamin MS, U. (2002). Front Pembela Islam, dalam Imam Tolkhah dan Choirul Fuad Yusuf. Jakarta: Departemen Agama RI Bidang Litbang Agama dan Diklat Keagamaan.

Albi, Anggito \& Setiawan, Johan. (2018). Metodelogi Penelitian Kualitatif . Sukabumi: CV Jejak.

Andi, Fachruddin. (2017). Dasar-Dasar Produksi TV: Produksi Berita, Feature, Dokumenter dan Teknik Editing. Jakarta: Prenadamedia Group.

Bungin, Burhan. (2015). Konstruksi Sosial Media Massa. Cet ke.3. hal. 110. Jakarta: Prenada Media, Prenada Media Grup.

Eriyanto. (2008). Analisis Wacana, Pengantar Teks Analisis Media. Yogyakarta: LKis Yogyakarta.

(2011). Analisis Framming Konstruksi Ideologi dan Politik Media. Yogyakarta: LKiS Yogyakarta.

Meolong, Lexy J. (2007). Metode Penelitian Kualitatif, Bandung, PT Remaa Rosdadakarta.

Morrisan. (2014). Teori Komunikasi Individu Hingga Massa. Jakarta: Prenadamedia, h. 34 . 
Muhammad, Amirudin. (1991). Latar Belakang Lahirnya Front Pembela Islam. Jakrta: PT. Insan Ilmu.

Nasrullah, Rulli. (2014). Teori dan Riset Media Siber (Cybermedia), Jakarta: Kencana.

Nurfitriyah, Mubarak Dinul. (2020). Analisis Teks Media Sebuah Pengantar Riset Jurnalistik, Sulawesi Selatan, IPN Press, hlm. 64.

Nursofya, Ayu Fitri. (2019). Strategi Rekrutmen Front Pembela Islam (FPI). https://repository.uinjkt.ac.id/dspace/bitstream/123456789/46419/1/AYU\% 20FITRI\%20NURSOFYA-FISIP.pdf.

Nurudin. (2004). Komunikasi Massa. Banding: Pustaka Pelajar.

Panggabean Rizal Samsu dan Taufik Adnan Amal. (2004). Politik Syariat Islam dari Indonesia Hingga Nigeria, Jakarta, Pustaka Alvabet.

Perdana, Andhika., Karlinah, Siti \& Yudhapramesti, Pandan. (2012). Pemberitaan Front Pembela Islam dalam Majalah Berita Mingguan Tempo. E-journal Mahasiswa Universitas Padjadjaran vol. 01, no. 01 (2012). Diterbitkan oleh Universitas Padjadjaran, tahun 2012. http://jurnal.unpad.ac.id/ejournal/article/view/1231/pdf.

Setya, Mustafa Pinto, et al. (2020). Metodelogi Penelitian Kuantitatif, Kualitatif, dan Tindakan Kelas dalam Pendidikan Olahraga. Malang, Fakultas Ilmu Keolahragaan Universitas Negeri Malang.

Suara.com, Alasan Pemerintah Jadikan FPI Organisasi Terlarang. (https://www.suara.com/news/2020/12/30/125647/ini-alasan-pemerintahjadikan-fpi-organisasi-terlarang).

Syaefudin, Machfoed. (2014). Reinterpretasi Gerakan Dakwah Front Pembela Islam (FPI). Jurnal Dakwah Indonesia, vol 34, no 2 (2014). Diterbitkan oleh UIN Walisongo tahun 2014. https://journal.walisongo.ac.id/index.php/dakwah/article/view/486/438.

Tempo.co.https://interaktif.tempo.co/proyek/aksi-fpi-dari-masa-ke-masa/index.html.

Umar. (2013). Metode Penelitian Untuk Skripsi dan Thesis. Jakarta, Rajawali. 